\title{
Effect of Zr Content on the Distribution Characteristic of the 14H and 18R LPSO Phases
}

\author{
Wanneng Zhang ${ }^{a}$ (1) , Zhongxue Feng ${ }^{a *}$ (1) , Xu Li ${ }^{a}$, Yuming Chen ${ }^{a}$ \\ ${ }^{a}$ Kunming University of Science and Technology, School of Materials Science and Engineering, \\ Kunming, 650093, China
}

Received: September 25, 2019; Revised: October 17, 2019; Accepted: November 11, 2019

\begin{abstract}
Zirconium ( $\mathrm{Zr}$ ) is an essential element in $\mathrm{Mg}-\mathrm{Zn}$ and $\mathrm{Mg}-\mathrm{Zn}-\mathrm{Y}$ system magnesium alloys. In this study, an interesting phenomenon that the content of $\mathrm{Zr}$ element could influence the size and the morphology of the long period stacking ordered (LPSO) phases, which has never been reported by previous works before. The $\mathrm{Mg}_{98.5-\mathrm{x}} \mathrm{Zn}_{0.5} \mathrm{Y}_{1} \mathrm{Zr}_{\mathrm{x}}(\mathrm{x}=0,0.1,0.2$ and 0.3 at. \%) magnesium alloys were fabricated by directional solidification, and the effects of the $\mathrm{Zr}$ content on the distribution characteristics of the bulk LPSO phases $(18 \mathrm{R})$ and the lamellar LPSO phases $(14 \mathrm{H})$ were investigated. The directional solidification technology showed good controllability in LPSO phase's distribution, and the morphology of LPSO phases in $\mathrm{Mg}_{98.5-\mathrm{x}} \mathrm{Zn}_{0.5} \mathrm{Y}_{1} \mathrm{Zr}_{\mathrm{x}}(\mathrm{x}=0,0.1,0.2$ and 0.3 at. \%) alloys were observed clearly. The results showed that the amount and the morphology of the $14 \mathrm{H}$ and $18 \mathrm{R}$ LPSO phases within grains continuously decreased with the $\mathrm{Zr}$ content increasing. The continuous $14 \mathrm{H}$ lamellar structure changed to discontinuous. In addition, $\mathrm{Zr}$ element exhibited purification ability on the grain boundaries and refined effect on the $14 \mathrm{H}$ and $18 \mathrm{R}$ LPSO phases. This can be attributed to the influence of $\mathrm{Zr}$ atoms on stacking fault energy (SFE) and the attraction of $\mathrm{Zr}$ atoms to $\mathrm{Mg}$ atoms.
\end{abstract}

Keywords: Mg-Zn-Y magnesium alloys, Long Period Stacking Ordered (LPSO) phases, Stacking Fault Energy (SFE), Zirconium (Zr).

\section{Introduction}

In recent years, the high-performance lightweight magnesium alloys have received many attentions in various fields, such as aviation, aerospace, transportations, chemicals, 3C (Computer, Communication and Consumer electronics) and other industries ${ }^{1-6}$. Currently, according to the reports, the consumption of magnesium alloys has increased to the third place as structural material, second only to iron-based and aluminum-based alloys ${ }^{7}$. The ZK60 magnesium alloy is one of the commercial wrought magnesium alloys with high strength. However, ZK60 is still limited in its application due to their poor room temperature ductility compared with commercial aluminum alloys ${ }^{8-14}$. In order to improving the ductility of ZK60 at room temperature, an effective approach is transforming the brittle phase to ductility phase. Therefore, with the addition of rare earth (RE) elements, the brittle $\mathrm{Mg}-\mathrm{Zn}$ phase can transform to LPSO phases, which exhibit good ductility ${ }^{15-19}$. Furthermore, the RE elements not only purifies the magnesium alloy matrix, but also contribute to refine the grains. In the $\mathrm{Mg}-\mathrm{M}-\mathrm{RE}$ systems $(\mathrm{M}=\mathrm{Al}$, $\mathrm{Ni}, \mathrm{Cu}$ and $\mathrm{Zn} ; \mathrm{RE}=\mathrm{Y}, \mathrm{Gd}, \mathrm{Dy}, \mathrm{Ho}, \mathrm{Er}, \mathrm{Tb}$ and $\mathrm{Tm}$ ) alloys, LPSO phase would strongly hinder the basic slip system through the formation of the kink binds during the loading and deformation process of the magnesium alloys, thereby RE-magnesium alloys not sacrifice toughness, and keep high strength $^{20-22}$. Generally, $14 \mathrm{H}$ and $18 \mathrm{R}$ are the most common LPSO phases which in the form of block and lamellar in magnesium alloys, and studies have found that there is a certain

*e-mail: fzxue2003@163.com orientation relationship between $14 \mathrm{H}$ and $18 \mathrm{R}^{23,24}$. Due to the similar brick-wall structure between the $14 \mathrm{H}$ phase and the magnesium matrix, the breakage of one brick could not cause a wall to collapse. Therefore Mg-Zn-Y system alloys can be expected to be good candidates for high strength and high toughness magnesium alloy materials.

$\mathrm{Zr}$ is an essential alloying element for both $\mathrm{Mg}-\mathrm{Zn}$ and $\mathrm{Mg}-\mathrm{Zn}-\mathrm{Y}$ system alloys. Although the content of $\mathrm{Zr}$ in magnesium matrix is very low, its effectively refined effect on $\mathrm{Mg}$ grains, so it deserves much attention for many researchers. It is widely accepted that the $\mathrm{Zr}$ element can be the powerful nucleant of magnesium and improve the nucleation amount of grains due to the similarity in the lattice parameters between $\mathrm{Zr}$ and $\mathrm{Mg}$. However, the trace $\mathrm{Zr}$ elements are difficult to find by common ways, there is no direct evidence to prove the refinement mechanism of $\mathrm{Zr}$ element in magnesium alloys ${ }^{25,26}$. Not only $\mathrm{Zr}$ element has the grain refined effect, but the other effects cannot be ignored as well. Robson and Paa-Rai ${ }^{27}$ found that $\mathrm{Zr}$ can reduce the amount of aging precipitates and decrease the age hardening effect on magnesium matrix. It is attributed to the precipitation of coarse $\mathrm{Zn}-\mathrm{Zr}$ phases which inhibit the precipitation of $\beta^{\prime}-\mathrm{MgZn}$ phase. Because of the lattice distortion releasing and thermal conductivity improving, the solubility content of $\mathrm{Zn}$ would decrease significantly with the $\mathrm{Zr}$ adding ${ }^{27,28}$. Li et al. ${ }^{29}$ investigated the microstructure and thermal conductivity of $\mathrm{Mg}-2 \mathrm{Zn}-\mathrm{Zr}$ alloy, they found the main precipitated phases of $\mathrm{Mg}-2 \mathrm{Zn}-\mathrm{Zr}$ alloy are $\mathrm{Zn}, \mathrm{Zr}$ and $\mathrm{Zn}_{2} \mathrm{Zr}_{3}$, and they concluded that these phases improved both the thermal conductivity and the strength of $\mathrm{Mg}-2 \mathrm{Zn}-\mathrm{Zr}$ 
alloy. Although the reasons of these effects were not clearly, the fact that the $\mathrm{Zr}$ element contributes to improving the mechanical and physical properties of the $\mathrm{Mg}-\mathrm{Zn}$ series alloys cannot be ignored.

In present work, the Mg-Zn-Y alloys were prepared by direction solidification to control, and the distribution of LPSO phase in Mg-Zn-Y alloys were observed obviously, and the relationship between the content of $\mathrm{Zr}$ and the distribution characteristics of LPSO phase were also established in this study. Furthermore, the distribution characteristics of LPSO phases in $\mathrm{Mg}-\mathrm{Zn}-\mathrm{Y}$ alloys changed with the $\mathrm{Zr}$ element adding which might prove a new perspective to control the growth process of LPSO phases and provide a new idea for designing high strength and high toughness $\mathrm{Mg}-\mathrm{Zn}-\mathrm{Y}$ system alloys.

\section{Experimental}

\subsection{Material preparation and heat treatments}

The master ingots with different nominal composition $\left(\mathrm{Mg}_{98.5-\mathrm{x}} \mathrm{Zn}_{0.5} \mathrm{Y}_{1} \mathrm{Zr}_{\mathrm{x}}, \mathrm{x}=0,0.1,0.2\right.$ and 0.3 at. \%) were prepared by resistance furnace in an argon atmosphere. pure $\mathrm{Mg}(>99.8 \%)$, pure $\mathrm{Zn}(>99.8 \%), \mathrm{Mg}-25 \% \mathrm{Y}$ (wt. \%) and $\mathrm{Mg}-25 \% \mathrm{Zr}$ (wt. \%) were used as the raw materials. The ingots were re-melted in a self-manufactured furnace as previously described in $\mathrm{Xu}$ et al. ${ }^{30}$ and $\mathrm{Li}$ et al. ${ }^{31}$. The ingots were putted into stainless steel crucibles with a 28/30 $\mathrm{mm}$ diameter (inside/outside diameter) and a length of $165 \mathrm{~mm}$. The directional solidification process was carried out in the argon atmosphere. The specimens were heated to $1003 \mathrm{~K}$ over $1 \mathrm{~h}$ and thermally stabilized for $2 \mathrm{~h}$. After that, turned off the bottom set of resistive wires, cooled the bottom of crucibles by a water-cooled copper base, and then controlled the top set of resistive wires to keep the samples cool with $10^{\circ} \mathrm{C} / \mathrm{min}$. At the end of the experiment, when the temperature went down to $673 \mathrm{~K}$, turned off all the power and remained the sample in the furnace until the temperature down to room temperature.

\subsection{Microstructural characterizations}

The chemical composition of $\mathrm{Mg}_{98.5-\mathrm{x}} \mathrm{Zn}_{0.5} \mathrm{Y}_{1} \mathrm{Zr}_{\mathrm{x}}$ ( $\mathrm{x}=0$, $0.1,0.2$ and 0.3 at. \%) alloys was measured by inductively coupled plasma-atomic emission spectrometry (ICP-AES), as listed in Table 1 . The casting samples were mechanically polished and etched with $4 \%$ nital, an ethanol solution of picric acid and glacial acetic acid $(2.0 \mathrm{~g}$ picric acid, $5 \mathrm{ml}$ glacial acetic acid, $5 \mathrm{ml}$ water and $25 \mathrm{ml}$ ethanol). Microstructures of specimens were analyzed by optical microscope (OM) and FEI SIRION 200 scanning electron microscopy (SEM) equipped with an Oxford energy dispersive X-ray spectrometer

Table 1. The chemical composition of the as-cast alloy (at. \%).

\begin{tabular}{cccccc}
\hline \multirow{2}{*}{ Alloys } & \multirow{2}{*}{$\begin{array}{c}\text { Nominal } \\
\text { composition }\end{array}$} & \multicolumn{4}{c}{ Measured composition } \\
\cline { 3 - 6 } & $\mathrm{Mg}_{98.5} \mathrm{Y}_{1} \mathrm{Zn}_{0.5}$ & 0.86 & 0.42 & - & Bal. \\
\hline $\mathrm{A}$ & $\mathrm{Y}$ & $\mathrm{Zn}$ & $\mathrm{Zr}$ & $\mathrm{Mg}$ \\
\hline $\mathrm{B}$ & $\mathrm{Mg}_{98.4} \mathrm{Y}_{1} \mathrm{Zn}_{0.5} \mathrm{Zr}_{0.1}$ & 0.87 & 0.44 & 0.08 & Bal. \\
\hline $\mathrm{C}$ & $\mathrm{Mg}_{98.3} \mathrm{Y}_{1} \mathrm{Zn}_{0.5} \mathrm{Zr}_{0.2}$ & 0.85 & 0.43 & 0.16 & Bal. \\
\hline $\mathrm{D}$ & $\mathrm{Mg}_{98.2} \mathrm{Y}_{1} \mathrm{Zn}_{0.5} \mathrm{Zr}_{0.3}$ & 0.89 & 0.42 & 0.25 & Bal. \\
\hline
\end{tabular}

(EDS). Characterization of LPSO structure was performed in a JEOL JEM 2100F FEGTEM transmission electron microscopy operating at $200 \mathrm{KV}$.

\subsection{Atomic model and calculation details}

The model was built on the super-cell of $\operatorname{Mg}(\mathrm{a} \times \mathrm{b} \times$ $\mathrm{c}=5 \times 5 \times 3, \mathrm{a}, \mathrm{b}$, and $\mathrm{c}$ represent directions of $\mathrm{Mg}$ crystal lattice respectively). The total number of atoms in super-cell was 150 . One $\mathrm{Mg}$ atom was replaced by $\mathrm{Zr}$ atom. In this study, the fractional coordinates of $\mathrm{Zr}$ atom was $(0.67,0.33,0.50)$. The crystal structure of the calculation model was showed in Figure 1. Our calculations were performed using the Cambridge Serial Total Energy Package Code (CASTEP) based on DFT. The Generalized Gradient Approximation (GGA) was employed to evaluate exchange-correlation energy. Ultra-soft pseudo-potentials were used for electron-ion interactions and the electron wave function was expanded using plane waves. $\mathrm{Mg} 2 \mathrm{p}^{6} 3 \mathrm{~s}^{2}$ and $\mathrm{Zr} 4 \mathrm{~s}^{2} 4 \mathrm{p}^{6} 4 \mathrm{~d}^{2} 5 \mathrm{~s}^{2}$ were treated as valence electrons. The cut-off energy was $380 \mathrm{eV}$ and the K-point was $12 \times 12 \times 6$ to ensure the convergence of the system energy and configuration at the plane wave group level.

\subsection{Stacking fault energy calculation method}

According to the thermodynamic calculation model of the basal plane stacking fault energy in the hexagonal pure metal, when the stacking fault occurs in close-packed hexagonal metal, the close-packed hexagonal (hcp) of ABABAB …..... arrangement in the stacking fault regions are changed to face-centered cubic (fcc) of $\cdots \cdots \cdots$. ABABABCBABA $\cdots \cdots \cdots$ arrangement in (0001) plane. We characterized the stacking fault energy of magnesium by calculating the energy required for the hcp $\rightarrow$ fcc structural transformation. In the calculation process, the variables are $\mathrm{Zr}$ content and temperature. When the $\mathrm{Zr}$ content is selected as the variable to calculate the stacking fault energy, the temperature was fixed to $800 \mathrm{~K}$ (the most common solid solution temperature ${ }^{32}$, the elements in the $\mathrm{Mg}$ matrix more inclined to segregation at stacking

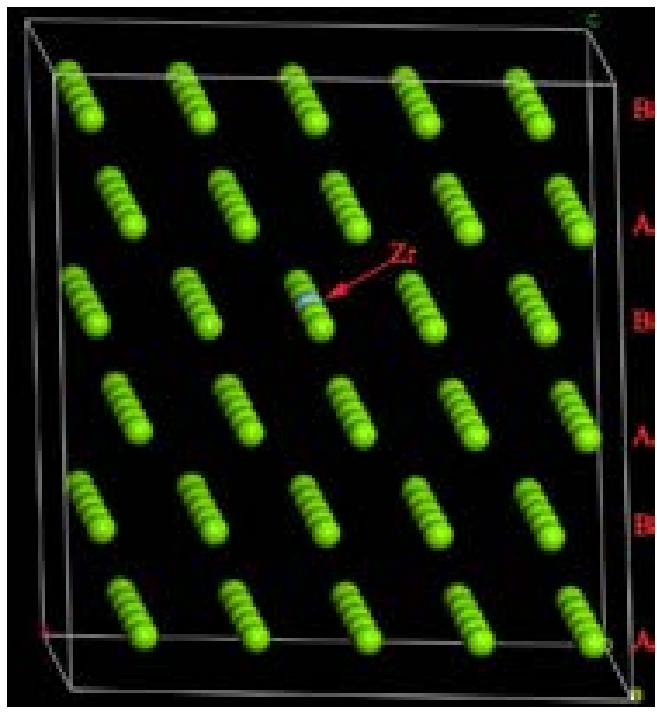

Figure 1. The crystal structure of the calculation model. 
fault position, and this facilitates precipitation of the second phase). In addition, the total amount of $\mathrm{Mg}$ and $\mathrm{Zr}$ elements in the calculation process are regarded as $100 \%$, and the linear relationship is performed by taking the value of $\mathrm{Zr}$ content (the value taken distance was divided into 0.0005 at. \%). Similarly, when the temperature is selected as the variable, the calculation was performed by $\mathrm{Mg}-0.2 \mathrm{Zr}$ (at. \%), and the temperature setting range was from $300 \mathrm{~K}$ to $900 \mathrm{~K}$ in the heat treatment temperature range (the value taken distance was divided into $50 \mathrm{~K}$ ).

\section{Results}

The microstructure of A, B, C and D alloys were showed in Figure $2 a-d\left(a_{1}-d_{1}\right)$ and Figure 3a-d. It mainly consisted of well-development primary $\alpha-\mathrm{Mg}$ and LPSO phases consisted

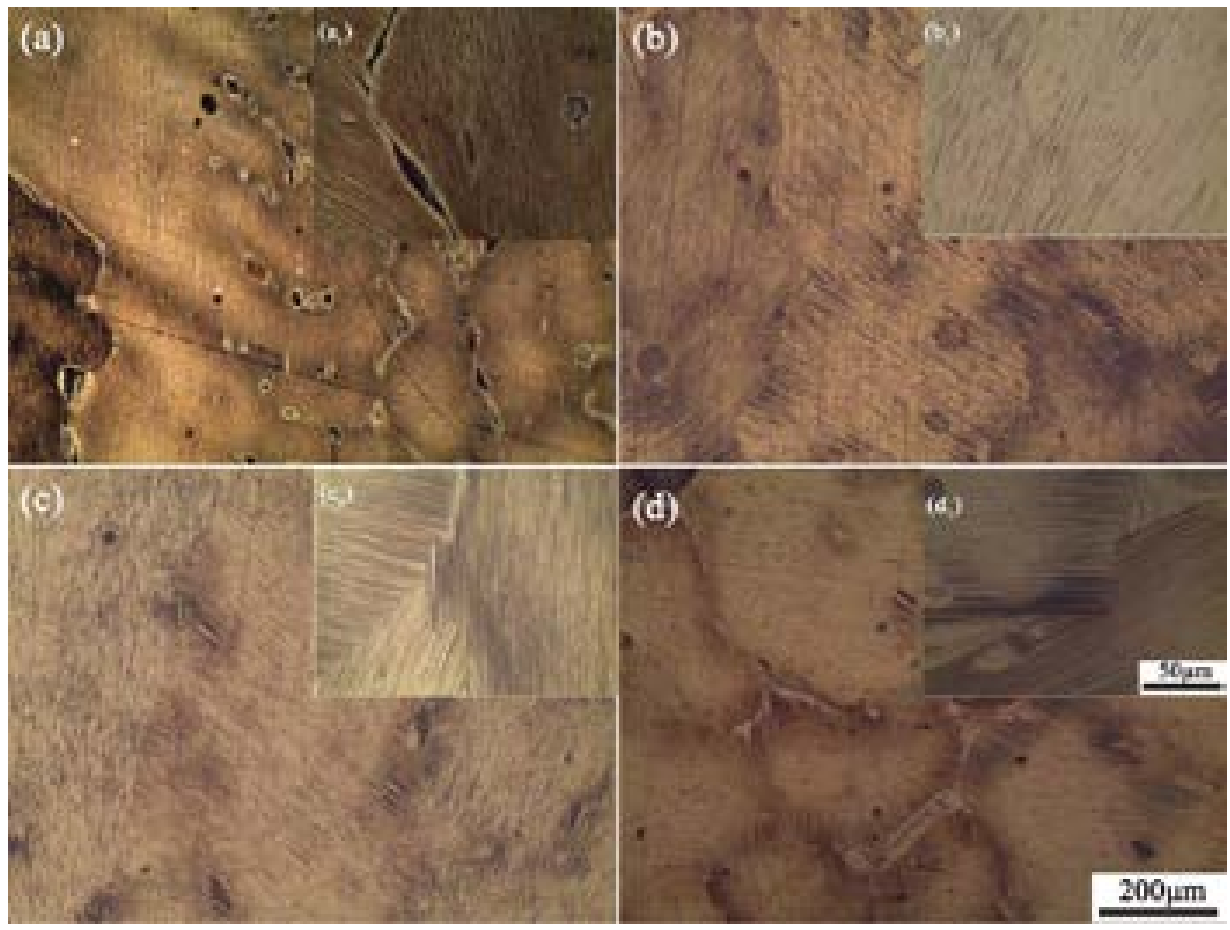

Figure 2. OM images of Mg-Zn-Y magnesium alloys with different content of Zr: (a) A alloy; (b) B alloy. (c) C alloy; (d) D alloy; (a), $\left(b_{1}\right),\left(c_{1}\right)$ and $\left(d_{1}\right)$ were zoom in of images $(a),(b),(c)$, and $(d)$, respectively.

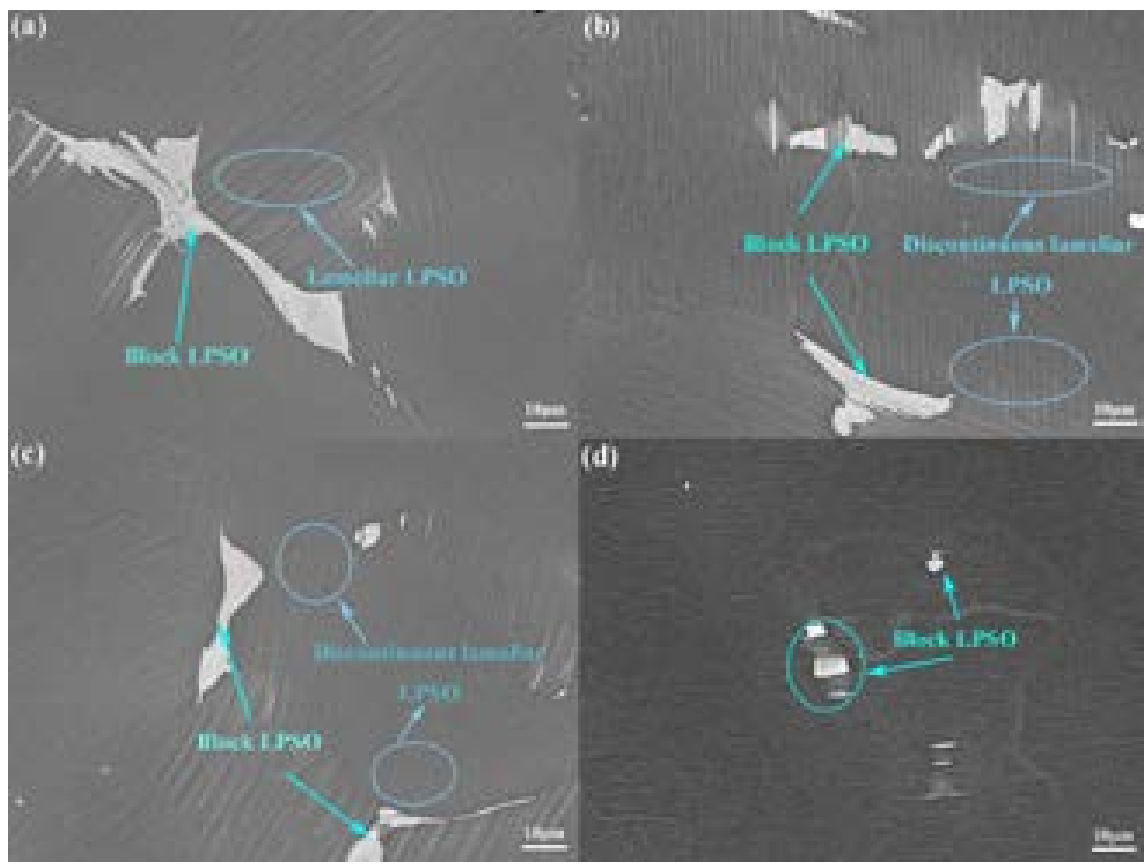

Figure 3. Typical SEM images of Mg-Zn-Y magnesium alloys with different content of Zr: (a) A alloy; (b) B alloy; (c) C alloy; (d) D alloy. 
by the bulk phases and the lamellar structure phases. The bulk phases in the grain boundary were 18R LPSO phases and the lamellar structures within grains were 14H LPSO phases, as shown in Figure $2 \mathrm{a}-\mathrm{d}\left(\mathrm{a}_{1}-\mathrm{d}_{1}\right)$. The crystal structure of the lamellar structure LPSO phases and the microstructure in the A alloy was examined by TEM, as shown in Figure $4 a$, $b$ and Figure 5. The type of the bulk phases and the lamellar phases was also identified in detail in our previous study ${ }^{30,33}$. As seen in Figure 2, the changes of distribution characteristics of LPSO phases in A, B, C and D alloys were clearly observed in this study. Figure $2\left(a, a_{1}\right)$ presented that the $14 \mathrm{H}$ LPSO phases were parallel along their longitudinal axis within grains, and showed obvious orientation. The $14 \mathrm{H}$ LPSO phases in the B alloy were finer than the A alloy and the continuous lamellar structure changed to discontinuous, as showed in Figure $2\left(b, b_{1}\right)$. Additionally, the grain boundary was broad and some bulk phases appeared in the grain boundary, as showed in the Figure 2a. However, in the B, C, and D alloys, the grain boundary became finer and cleaner than the A alloy, as showed in Figure $2 b-d$. These findings demonstrated that $\mathrm{Zr}$ have a purity effect on grain boundary and affect the morphology and distribution of $14 \mathrm{H}$ and $18 \mathrm{R}$ as well. With increasing the content of $\mathrm{Zr}$ from 0.1 to 0.2 at. \%, the amount and the size of the 14H LPSO phases were continuously decreasing, as showed in Figure 3a-c. Particularly, when the $\mathrm{Zr}$ element was adding to 0.3 at. $\%$, most of the $14 \mathrm{H}$ LPSO phases disappeared, there were almost no $14 \mathrm{H}$ LPSO phases in Mg matrix. Similarly, the $18 \mathrm{R}$ phase has same trend in morphology and amount compared with $14 \mathrm{H}$, and it showed that the bulk $18 \mathrm{R}$ phases are finer and more dispersed with the $\mathrm{Zr}$ content increasing, as shown in Figure 3a-d. This further proved that $\mathrm{Zr}$ had an influence on the distribution characteristic of the $14 \mathrm{H}$ phases and $18 \mathrm{R}$ phases. Furthermore, due to the difference between A, B, C, and D alloys, this suggested that the addition of $\mathrm{Zr}$ would break the balance of $14 \mathrm{H}$ and $18 \mathrm{R}$ which are presented in Figure 3b-d.
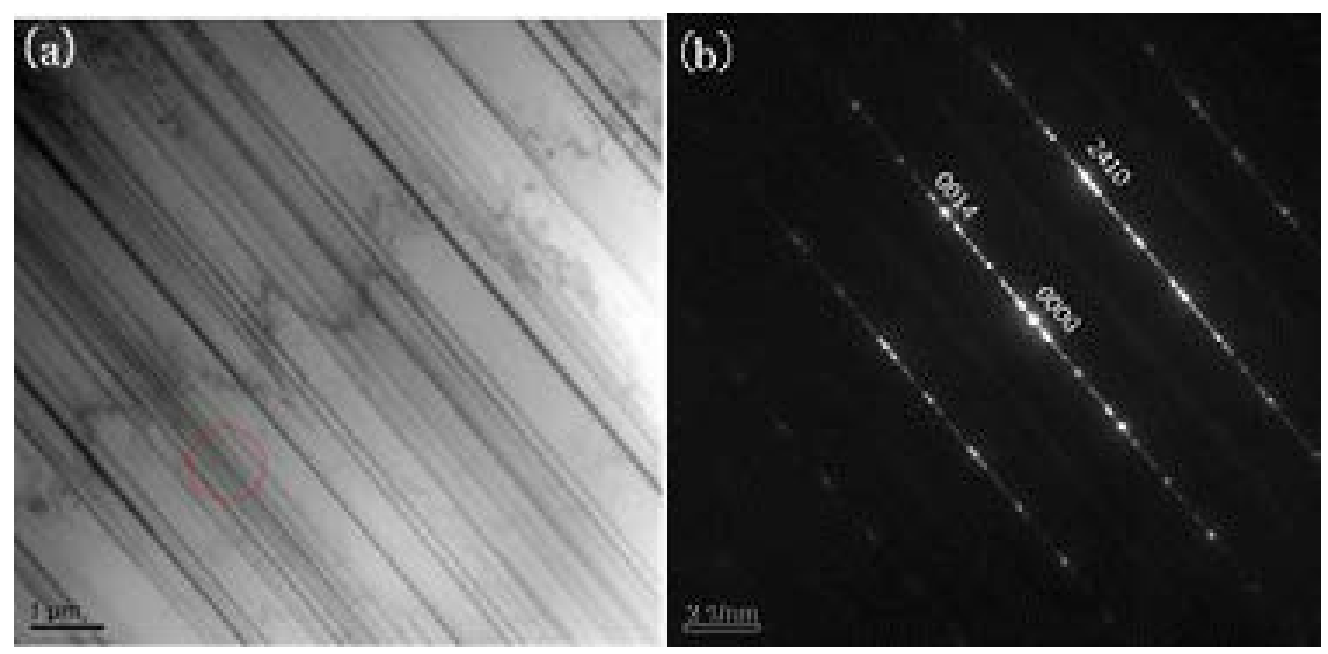

Figure 4. (a) The bright-field TEM image of the $\mathrm{Mg}_{9.5} \mathrm{Zn}_{0.5} \mathrm{Y}_{1}$ alloy; (b) The [10 $\left.\overline{3} 0\right]$ Selected Area Electron Diffraction (SAED) of the lamellar structure phase (indicated by red circle in (a)).

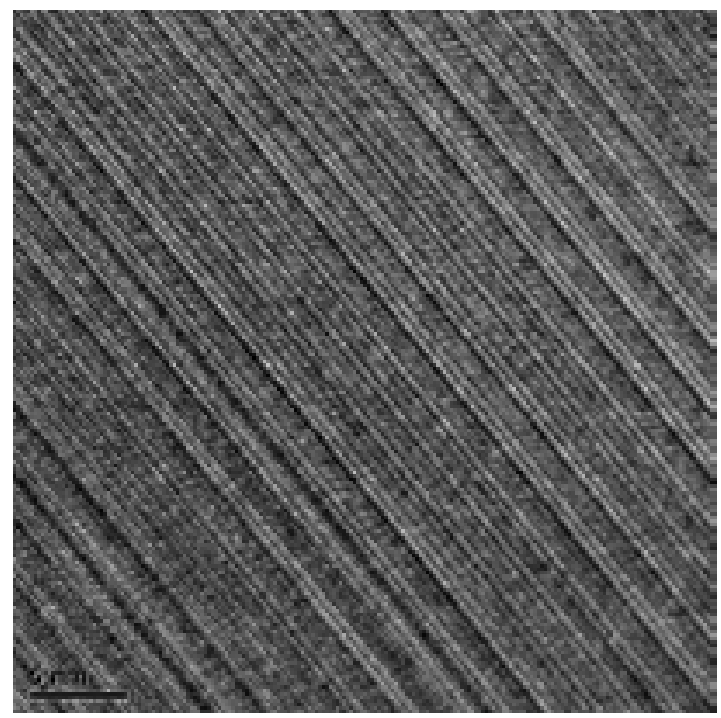

Figure 5. HRTEM images of the microstructures of the $\mathrm{Mg}_{98.5} \mathrm{Zn}_{0.5} \mathrm{Y}_{1}$ matrix and lamellar structure. 


\section{Discussion}

From the results obtained in the present study, two important conclusions can be concluded. Firstly, adding $\mathrm{Zr}$ elements beneficially refine the $14 \mathrm{H}$ LPSO and $18 \mathrm{R}$ LPSO phases. With the content of $\mathrm{Zr}$ increasing from 0.1 at. \% to 0.3 at. $\%$, the amount and the size of the $14 \mathrm{H}$ LPSO phases within grains continuously decreased. The discontinuous lamella was similar to the 14H LPSO phase in the Mg-2.0Gd-1.2Y$\mathrm{Zn}-0.2 \mathrm{Zr}$ (at. \%) alloy reported by Honma et al. ${ }^{34}$. When $\mathrm{Zr}$ content increasing to 0.3 at. $\%$, a few bulk phases would occur in the grain, as showed in Figure 3b-d. Secondly, $\mathrm{Zr}$ had a significant purity and refine effect on the grain boundary. The grain boundary became finer and cleaner than those without $\mathrm{Zr}$ adding. Based on above discussions, a four-step microstructure evolution mechanism can be established, and the schematic illustration was proposed in Figure 6, and the main reason can be summarized as follows:

When $\mathrm{Zr}$ adding to the $\mathrm{Mg}_{98.5} \mathrm{Zn}_{0.5} \mathrm{Y}_{1}$ alloy, the change of SFE play an important role in decreasing the amount of $14 \mathrm{H}$ and 18R LPSO phase. According to previous reports, the formation processes of the LPSO phases were close connected with the SFE of the matrix ${ }^{33,35-37}$. In order to understand the effect of the $\mathrm{Zr}$ content on the distribution characteristic of the LPSO phases, the SFE of the magnesium matrix with different $\mathrm{Zr}$ content are calculated as following equation ${ }^{38,39}$ :

$\gamma=\frac{1}{N_{0}^{1 / 3} V^{2 / 3}}\left(\sum_{i}^{n} X_{i} \Delta G_{i}^{\alpha \rightarrow \beta}+\frac{1}{2} \sum_{i}^{n} \sum_{j}^{n} \Delta W_{i j}^{\alpha \rightarrow \beta} X_{i} X_{j}\right)$

where $\mathrm{N}_{0}$ is Avogadro constant and $\mathrm{V}$ is molar volume of alloys. $\Delta G_{i}^{\alpha \rightarrow \beta}$ is free energy change of the structure transition of ' $i$ ' element. $X_{i}$ and $X_{j}$ is the molar fraction of ' $i$ ' and ' $j$ ' element, respectively. $\Delta W_{i j}^{\alpha \rightarrow \beta}$ is the interaction factors between ' $i$ ' and ' $j$ ' element $(i \neq j)$ in the process of structural transformation.

This equation was deduced and proved in our previous works $^{38,39}$. Table 2 showed the numerical values and functions used for the thermodynamic calculations. The calculation results were illustrated in Figure 7. According to the results,
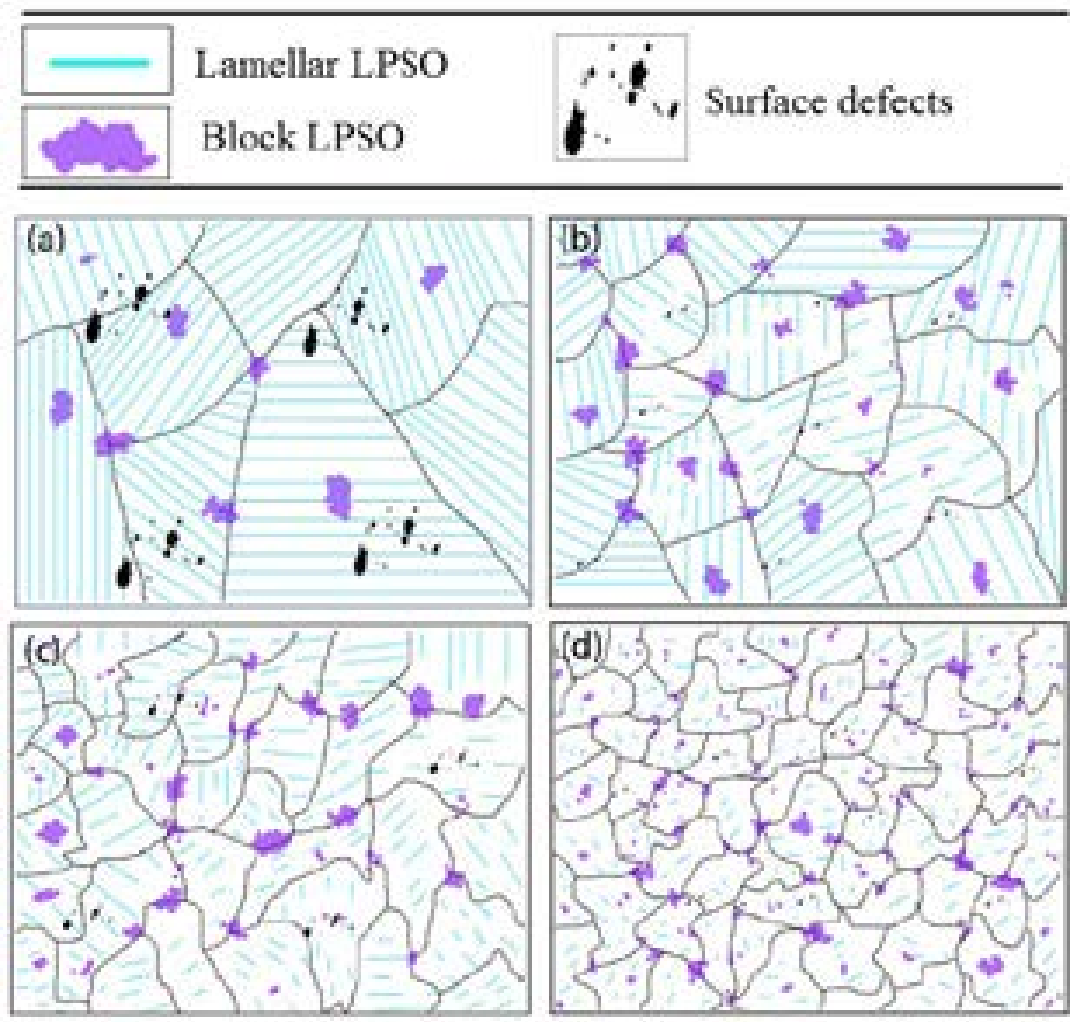

Figure 6. Schematic illustration for microstructure evolution of (a) A alloy; (b) B alloy; (c) C alloy; (d) D alloy.

Table 2. Numerical values and functions used for the thermodynamic calculations.

\begin{tabular}{|c|c|c|c|c|c|c|c|c|}
\hline \multirow{2}{*}{ parameter } & \multicolumn{2}{|c|}{$\Delta G_{i}^{\alpha \rightarrow \beta}=a_{i}+b_{i} T$} & & \multicolumn{2}{|c|}{${ }^{k} L_{i j}^{\alpha \rightarrow \beta}=a_{i j}+{ }^{k} b_{i j} T$} & & \multicolumn{2}{|c|}{$\Delta W_{i j}^{\alpha \rightarrow \beta}=A_{i j}+B_{i j} T$} \\
\hline & $a_{i}$ & $b_{i}$ & & $a_{i j}$ & ${ }^{k} b_{i j}$ & & $A_{i j}$ & $B_{i j}$ \\
\hline$\Delta G_{M g}^{\alpha \rightarrow \beta}$ & 2500.000 & -0.900 & ${ }^{k} L_{M g, Z r}^{\alpha \rightarrow \beta}$ & -10872.000 & 18.093 & $\Delta W_{M g, Z r}^{\alpha \rightarrow \beta}$ & -10.839 & 0.018 \\
\hline$\Delta G_{Z r}^{\alpha \rightarrow \beta}$ & 7302.056 & -0.703 & & & & & & \\
\hline
\end{tabular}

Note: $\alpha \rightarrow \beta$ represents the energy difference between the two structures of hcp and fcc 
the tendency of SFE increase with the atomic percent of $\mathrm{Zr}$ increasing, as shown in Figure $7 \mathrm{a}$. This suggested that adding $\mathrm{Zr}$ element could increase SFE. Conversely, with the temperature increasing, the value of SFE reduced, as shown in Figure $7 b$, and the lower SFE could benefit to generate LPSO phases. This was the main reason why the LPSO phase was much easier to grow during directional solidification process.

However, the SFE not increased sharply with the atomic percent of $\mathrm{Zr}$ increasing. This result did not match the obviously change of the $14 \mathrm{H}$ and $18 \mathrm{R}$ LPSO phases morphology and could not explain why the continuous lamellar structure $14 \mathrm{H}$ LPSO phase changed into discontinuous. There should be another reason for influence the forming process of the $14 \mathrm{H}$ and 18R LPSO phases. In order to investigating the reason of the $14 \mathrm{H}$ and 18R LPSO phases distribution characteristics with $\mathrm{Zr}$ element adding, the electron density between $\mathrm{Mg}$ and $\mathrm{Zr}$ atoms was calculated by first principle. The electron density of (001) lattice plane was showed in Figure 8. It can be found that the electron density around $\mathrm{Zr}$ atom was higher than $\mathrm{Mg}$ atoms and exhibited locality property. The higher electron density would increase the attractive force between $\mathrm{Zr}$ atoms and $\mathrm{Mg}$ atoms. Because the stacking fault energy in magnesium matrix changed the atomic arrangement from $\mathrm{ABAB}$ to $\mathrm{ABCABC}^{39}$, so the attractive force between $\mathrm{Zr}$ atoms and $\mathrm{Mg}$ atoms increasing would increase the local energy consumed by misplacing atomic layers and obstruct the diffusion of elements. This would improve the energy barrier for generating $14 \mathrm{H}$ and $18 \mathrm{R}$, and break the growth channel of the $14 \mathrm{H}$ LPSO phases. Finally, causing the continuous lamellar structure to discontinuous. These results further explained the change of distribution characteristics of LPSO phase with adding trace content of $\mathrm{Zr}$, even though SFE not increased obviously.

Besides that, because both of the $\mathrm{Zr}$ atoms and $\mathrm{Mg}$ atoms are hexagonal close packed lattice, the magnesium matrix could accept $\mathrm{Zr}$ element without severely energy increasing and crystal lattice distortion in the process of $\mathrm{Zr}$ adding. Therefore, there is not obviously energy difference between the $\mathrm{Zr}$ atoms located in grains and grain boundaries, unlike the common eutectic elements $\mathrm{Al}, \mathrm{Ca}$, and $\mathrm{Si}$, the segregation of $\mathrm{Zr}$ atoms in the grain boundaries are not easy to occur, and this keeps the entire system of the Mg-Zn- $-\mathrm{Zr}$ matrix in the lowest energy state. Meanwhile, $\mathrm{Zr}$ element could increase the attractive force between $\mathrm{Zr}$ atoms and $\mathrm{Mg}$ atoms, this force stimulates the bond between grains more tightly. These factors could contribute to the grain boundaries finer and cleaner. In addition, because the finer and cleaner grain boundaries represent more stable energy and less energy fluctuations, the energy of nucleation and growth of the $14 \mathrm{H}$ and $18 \mathrm{R}$ phases increases. This would reduce the bulk and lamellar structure in the grain.
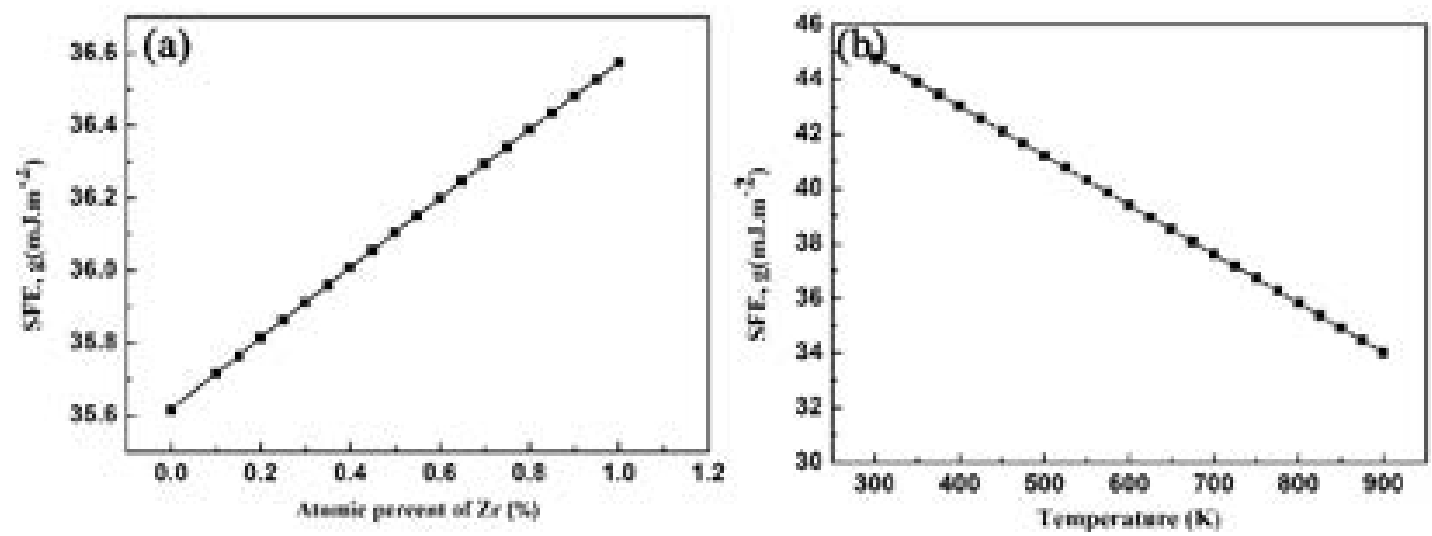

Figure 7. (a) Stacking fault energy (SFE) of Mg matrix with different content of $\mathrm{Zr}$; (b) SFE of Mg- $0.2 \mathrm{Zr}$ (at. \%) at different temperature.

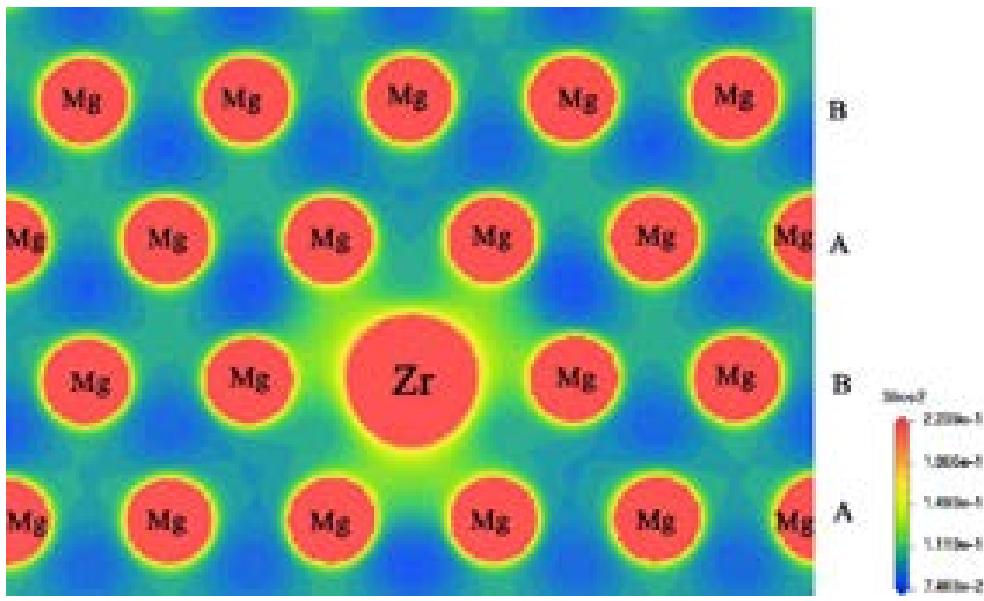

Figure 8. Electron density of $\left(\begin{array}{lll}0 & 0 & 1\end{array}\right)$ lattice plane. 


\section{Conclusions}

1. The amount and the morphology of the 14H LPSO phases within grains continuously decreased, and the continuous lamellar structure within grains transform to discontinuous with the $\mathrm{Zr}$ content increasing to 0.1 at. $\%$ and 0.2 at. $\%$. In addition, the bulk $18 \mathrm{R}$ phases are finer and more dispersed when $\mathrm{Zr}$ content adding to 0.3 at. \%.

2. In $\mathrm{B}, \mathrm{C}$ and $\mathrm{D}$ alloys, the grain boundaries are finer and cleaner than the A alloy. This can be attributed to the fact that the addition of the $\mathrm{Zr}$ element reduced the energy of the matrix and grain boundaries of the Mg-Zn-Y alloy.

3. According to the calculation results, $\mathrm{Zr}$ element would increase the SFE of magnesium alloy, then increase the energy of nucleation and growth of bulk phases and the lamellar phase, and cause the amount of $14 \mathrm{H}$ and 18R LPSO phases decreasing. Furthermore, because the $\mathrm{Zr}$ atom would increase the attractive force between $\mathrm{Zr}-\mathrm{Mg}$ atoms, this would break the growth channel of the lamellar structure and change the continuous lamellar structure to discontinuous.

\section{Acknowledgements}

This work was supported by the Yunnan Province Science Youth Experts Fund [2016FD033].

\section{References}

1. Joost WJ, Krajewski PE. Towards magnesium alloys for highvolume automotive applications. Scr Mater. 2017;128:107-12. http://dx.doi.org/10.1016/j.scriptamat.2016.07.035.

2. Chen X, Liu J,Pan F. Enhanced electromagnetic interference shielding in ZK60 magnesium alloy by aging precipitation. J Phys Chem Solids. 2013;74(6):872-8. http://dx.doi.org/10.1016/j.jpcs.2013.02.003.

3. Xianhua C, Yuxiao G, Fusheng P. . Research progress in magnesium alloys as functional materials. Rare Met Mater Eng. 2016;45(9):2269-74. http://dx.doi.org/10.1016/S18755372(17)30015-2.

4. Esmaily M, Svensson JE, Fajardo S, Birbilis N, Frankel GS, Virtanen S, et al. Fundamentals and advances in magnesium alloy corrosion. Prog Mater Sci. 2017;89:92-193. http://dx.doi. org/10.1016/j.pmatsci.2017.04.011.

5. Radha R, Sreekanth D. Insight of magnesium alloys and composites for orthopedic implant applications - a review. J. Magn. Alloys. 2017;5(3):286-312. http://dx.doi.org/10.1016/j. jma.2017.08.003.

6. Wang XJ, Xu DK, Wu RZ, Chen XB, Peng QM, Jin L, et al. What is going on in magnesium alloys? J Mater Sci Technol. 2017;7:1-3. http://dx.doi.org/10.1016/j.jmst.2016.11.017.

7. Samaniego A, Gusieva K, Llorente I, Feliu S Jr, Birbilis N. Exploring the possibility of protective surface oxides upon $\mathrm{Mg}$ alloy AZ31 via lutetium additions. Corros Sci. 2014;89:101-10. http://dx.doi.org/10.1016/j.corsci.2014.08.015.

8. Chen XR, Ning FK, Hou J, Le QC, Tang Y. Dual-frequency ultrasonic treatment on microstructure and mechanical properties of ZK60 magnesium alloy. Ultrason Sonochem. 2018;40(Pt A):433-41. http://dx.doi.org/10.1016/j.ultsonch.2017.07.027. PMid:28946443.

9. Hadadzadeh A, Wells MA. Analysis of the hot deformation of ZK60 magnesium alloy. J Magn Alloys. 2017;5(4):369-87. http://dx.doi.org/10.1016/j.jma.2017.09.002.
10. Ciccarelli D, El Mehtedi M, Jager A, Spigarelli S. Analysis of flow stress and deformation mechanism under hot working of ZK60 magnesium alloy by a new strain-dependent constitutive equation. J Phys Chem Solids. 2015;87:183-95. http://dx.doi. org/10.1016/j.jpcs.2015.08.020.

11. Karparvarfard SMH, Shaha SK, Behravesh SB, Jahed H, Williams BW. Microstructure, texture and mechanical behavior characterization of hot forged cast ZK60 magnesium alloy. J Mater Sci Technol. 2017;33(9):907-18. http://dx.doi.org/10.1016/j. jmst.2017.04.004.

12. Kim B, Baek SM, Lee JG, Park SS. Enhanced strength and plasticity of Mg-6Zn- $0.5 \mathrm{Zr}$ alloy by low-temperature indirect extrusion. J Alloys Compd. 2017;706:56-62. http://dx.doi. org/10.1016/j.jallcom.2017.02.206.

13. Yang Y, Jiang LH. Self-organization of adiabatic shear bands in ZK60 Magnesium alloy. Mater Sci Eng. 2016;655:321-30. http://dx.doi.org/10.1016/j.msea.2016.01.008.

14. Yang Y, Wang Z, Jiang LH. Evolution of precipitates in ZK60 magnesium alloy during high strain rate deformation. J Alloys Compd. 2017;705:566-71. http://dx.doi.org/10.1016/j. jallcom.2017.02.158.

15. Wang Y, Zhang Y, Gao W. Effect of Zr on the microstructures and mechanical properties of as-extruded $\mathrm{Mg}-2.3 \mathrm{Zn}-0.18 \mathrm{Y}-\mathrm{xZr}$ alloys. Int J Mod Phys B. 2017;31(16-19):1744001. http:// dx.doi.org/10.1142/S0217979217440015.

16. Luo SQ, Tang AT, Pan FS, Song K, Wang WQ. Effect of mole ratio of $\mathrm{Y}$ to $\mathrm{Zn}$ on phase constituent of $\mathrm{Mg}-\mathrm{Zn}-\mathrm{Zr}-\mathrm{Y}$ alloys. Trans Nonferrous Met Soc China. 2011;21(4):795-800. http:// dx.doi.org/10.1016/S1003-6326(11)60783-8.

17. Shahzad M, Waqas H, Rafi-ud-din, Qureshi AH, Wagner L. d. Rafi ud, A.H. Qureshi, L. Wagner, The roles of Zn distribution and eutectic particles on microstructure development during extrusion and anisotropic mechanical properties in a $\mathrm{Mg}$ Zn-Zr alloy. Mater Sci Eng A. 2015;620:50-7. http://dx.doi. org/10.1016/j.msea.2014.09.109.

18. Chen Q, Lin J, Shu DY, Hu CK, Zhao ZD, Kang F, et al. Microstructure development, mechanical properties and formability of Mg-Zn-Y-Zr magnesium alloy. Mater Sci Eng. 2012;554:129-41. http://dx.doi.org/10.1016/j.msea.2012.06.025.

19. Yang X, Wu SS, Lu SL, Hao LY, Fang XG. Refinement of LPSO structure in $\mathrm{Mg}-\mathrm{Ni}-\mathrm{Y}$ alloys by ultrasonic treatment. Ultrason Sonochem. 2018;40(Pt A):472-9. http://dx.doi.org/10.1016/j. ultsonch.2017.07.042. PMid:28946448.

20. Yokobayashi H, Kishida K, Inui H, Yamasaki M, Kawamura Y. Enrichment of $\mathrm{Gd}$ and $\mathrm{Al}$ atoms in the quadruple close packed planes and their in-plane long-range ordering in the long period stacking-ordered phase in the $\mathrm{Mg}-\mathrm{Al}-\mathrm{Gd}$ system. Acta Mater. 2011;59(19):7287-99. http://dx.doi.org/10.1016/j. actamat.2011.08.011.

21. Yang Q, Guan K, Li B, Meng F, Lv S, Yu Z, et al. Coexistence of $14 \mathrm{H}$ and 18R-type long-period stacking ordered (LPSO) phases following a novel orientation relationship in a cast Mg-Al-RE-Zn alloy. J Alloys Compd. 2018;766:902-7. http:// dx.doi.org/10.1016/j.jallcom.2018.07.053.

22. Lv S, Li Y, Lü X, Meng F, Yang Q, Han D, et al. The types and structures of the intermetallic phases in a cast Mg-4Al-15Gd-4Y-1Zn alloy. J Alloys Compd. 2018;731:6129. http://dx.doi.org/10.1016/j.jallcom.2017.10.093.

23. Hagihara K, Li Z, Yamasaki M, Kawamura Y, Nakano T. Strengthening mechanisms acting in extruded Mg-based longperiod stacking ordered (LPSO)-phase alloys. Acta Mater. 2019;163:226-39. http://dx.doi.org/10.1016/j.actamat.2018.10.016.

24. Guan K, Meng F, Qin P, Yang Q, Zhang D, Li B, et al. Effects of samarium content on microstructure and mechanical properties of Mg-0.5Zn-0.5Zr alloy. J Mater Sci Technol. 2019;35(7):136877. http://dx.doi.org/10.1016/j.jmst.2019.01.019.

25. Lee YC, Dahle AK, StJohn DH. The role of solute in grain refinement of magnesium. Metall Mater Trans, A Phys Metall 
Mater Sci. 2000;31(11):2895-906. http://dx.doi.org/10.1007/ BF02830349.

26. StJohn DH, Qian M, Easton MA, Cao P, Hildebrand Z. Grain refinement of magnesium alloys. Metall Mater Trans, A Phys Metall Mater Sci. 2005;36(7):1669-79. http://dx.doi.org/10.1007/ s11661-005-0030-6.

27. Robson JD, Paa-Rai C. The interaction of grain refinement and ageing in magnesium-zinc-zirconium (ZK) alloys. Acta Mater. 2015;95:10-9. http://dx.doi.org/10.1016/j.actamat.2015.05.012.

28. Elsayed A, Sediako D, Ravindran C. Solidification Behavior of $\mathrm{Mg}-\mathrm{Zn}$ and $\mathrm{Mg}-\mathrm{Zn}-\mathrm{Zr}$ Alloys Using In-Situ Neutron Diffraction. J Mater Eng Perform. 2015;24(6):2250-5. http:// dx.doi.org/10.1007/s11665-015-1497-y.

29. Li B, Hou L, Wu R, Zhang J, Li X, Zhang M, et al. Microstructure and thermal conductivity of Mg-2Zn-Zr alloy. J Alloys Compd. 2017;722(Suppl. C):772-7. http://dx.doi.org/10.1016/j. jallcom.2017.06.148.

30. Xu Z, Feng Z, Shi Q, Yang Y, Wang X. The microstructure of Mg98.5Zn0.5Y1 Alloy with long-period stacking ordered structure. Mater Trans. 2017;58(6):862-7. http://dx.doi. org/10.2320/matertrans.M2016440.

31. Li FB, Feng ZX, Cao Y, Shi QN. Research of impurity phase in single crystal pure magnesium prepared by directional solidification. Special Casting \& Nonferrous Alloys. 2015;35(2):208-11.

32. Wu YJ, Zeng XQ, Lin DL, Peng LM, Ding WJ. The microstructure evolution with lamellar 14H-type LPSO structure in an $\mathrm{Mg} 96.5 \mathrm{Gd} 2.5 \mathrm{Zn} 1$ alloy during solid solution heat treatment at 773K. J Alloys Compd. 2009;477(1):193-7. http://dx.doi. org/10.1016/j.jallcom.2008.10.126.

33. Luo $S$. Experimental and theoretical investigation of solid solution strengthening and second phase strengthening in Mg-Zn-Zr-Y alloys [dissertation]. Chongqing: Chongqing University; 2011.

34. Honma T, Ohkubo T, Kamado S, Hono K. Effect of Zn additions on the age-hardening of Mg-2.0Gd-1.2Y-0.2Zr alloys. Acta Mater. 2007;55(12):4137-50. http://dx.doi.org/10.1016/j. actamat.2007.02.036.

35. Liu H, Yan K, Yan J, Xue F, Sun J, Jiang J, et al. Precipitation behavior of $14 \mathrm{H}$ LPSO structure in single $18 \mathrm{R}$ phase $\mathrm{Mg}-\mathrm{Y}-\mathrm{Zn}$ alloy during annealing at $773 \mathrm{~K}$. Trans Nonferrous Met Soc China. 2017;27(1):63-72. http://dx.doi.org/10.1016/S10036326(17)60007-4.

36. Pan F-s, Luo S-q, Tang A-t, Peng J, Lu Y. Influence of stacking fault energy on formation of long period stacking ordered structures in $\mathrm{Mg}-\mathrm{Zn}-\mathrm{Y}-\mathrm{Zr}$ alloys, Prog. Nat. Sci-Mater. 2011;21(6):485-90.

37. Umantsev A, Ode M. Formation of long-period stacking fault structures in magnesium alloys. Comput Mater Sci. 2016;124(Suppl. C):173-82. http://dx.doi.org/10.1016/j.commatsci.2016.07.035.

38. Feng ZX, Zhang XY, Pan FS. Influence of solute and solute segregation on the stacking fault energy in HCP metals. Rare Met Mater Eng. 2012;41(10):1765-9.

39. Feng ZX, Zhang XY, Pan FS. Thermodynamic model for the influence of temperature on the stacking fault energy in $\mathrm{HCP}$ metals. Rare Met Mater Eng. 2012;41(9):1638-41. 